\title{
Anthropogenic pollutants: 10 years of progress in ecotoxicological studies and aquatic risk assessment
}

\section{STEFANIA GHEORGHE ${ }^{1, \text { \#, IRINA LUCACIU }}{ }^{1}$, IULIANA PAUN ${ }^{1}$, GABRIELA GEANINA VASILE $^{1}$, JANA PETRE $^{1}$, VASILE ION IANCU ${ }^{1}$, CATALINA STOICA $^{1}$, DANIEL MITRU ${ }^{1,2}$, MIHAI NITA-LAZAR ${ }^{1}$}

\author{
${ }^{1}$ National Research and Development Institute for Industrial Ecology ECOIND Bucharest, 71-73 Drumul Podul Dambovitei, \\ 060652, Bucharest, Romania \\ ${ }^{2}$ The Polytechnic University of Bucharest - Faculty of Chemistry Engineering \\ \# corresponding author (e-mail): stefania.gheorghe@incdecoind.ro
}

The market expansion due to globalization generated more anthropogenic contaminants, enhancing their negative impact on the environment. In order to prevent and balanced their negative effect, more rapid, sensitive and eco-friendly ecotoxicological studies as risk assessments were developed. Each country developed national programs to ensure the research infrastructure for implementation and development of new testing methodologies, generating new experimental data transferable to governmental authorities, economic agents and academia.

In this review, we intend to highlighted the progress of Romanian researchers in the last 10 years in the field of ecotoxicology and aquatic risk assessment. The studies focused on aquatic systems as a non-targeted system to the anthropogenic pollutants impact.

The implemented methodologies according with international requirements for chemical control like REACH Regulation, Detergents Regulation, Biocide Products Regulation or the Aquatic Risk Assessment Guidelines were presented.

The ecotoxicological effects of various contaminants such as detergents, pharmaceuticals, pesticides, biocides or heavy metals and environmental polluted samples (surface water, sediment or sludge) were provided.

Overall, the studies presented in our studies have a nationally novelty through the variety of test substances, the complexity of laboratory experiments and data processing. The research work has a continue applicability in industry and for control authorities. New accredited testing services that providing useful information about the chemicals and their impact on the environmental were introduced. In addition, the ecotoxicology studies and their challenges were a great source for professional training like PhD and master studies and for impact published papers.

Keywords: chemicals, ecotoxicity, aquatic, risk, bio-indicator, biomarker

The interest of scientists to identify, solve and prevent the environmental problems has become a priority in the context of population growth, waters contamination, global warming and ecosystems damage or their extinction [1].

Moreover, the human well-being led to chemical market expansion that have generated new anthropogenic contaminants in larger amounts, thus enhancing their negative impact on the environment. The ecotoxicology of anthropogenic contaminants became one of the most published life science topic, due to vast and complex research sources.

Ecotoxicology field is a complex scientific discipline base on principles of toxicology, biology, chemistry and ecology, being focused on the research of chemical compounds effects on living organisms, other than man. The ecotoxicology is separated in two section: pollutant dynamics - that evaluate the mobility, migration, transformation, degradation in different environmental area; and bio toxicology - that examine the effects of toxic compounds on sensitive biological systems correlated with field data [1].

This review intends to highlight the progress of Romanian research, especially from National Research and Development Institute for 
Industrial Ecology - ECOIND Bucharest, in the last 10 years in the field of anthropogenic pollutants ecotoxicology and their aquatic risk assessment.

\section{Trend of ecotoxicity studies}

The ecotoxicity studies were mainly aimed the environmental protection through the compliance of international norms by chemical industry. The studies have novelty through the variety of the test substances available on the national market (such as pesticides, surfactants, pharmaceutical compounds, biocides), the complex laboratory experiments (acute, subacute or chronic exposure tests using different organisms and high performance chemical detection new methods) and data analyses (such as risk characterization, REACH classification, threshold approach system or natural water classification after Persoone 2003).

The research studies performed in the last 10 years match the international rising trend of scientific researches in Thomson ISI Web of Knowledge - Web of Science Platform (Fig. 1). An exponential increase of published studies in the field of chemicals ecotoxicology was observed.

The same trend is maintained also for biotests studies or risk assessments studies (Fig. 2). The Library revealed more than 2300 papers published in the same period. The high interest for environmental ecotoxicity studies have been also maintained in 2019. At the start of 2019, search of "ecotoxicity" topic in Wiley Online

more than 8500 studies were obtained based on a "ecotoxicology" topic search in Science Direct Platform. The scientists interest is focused booth on fundamental and applicative researches. The fallowed issues are covered: to testing new toxicants, to develop new eco-friendly biotests, to find new acceptable environmentally technologies applied in chemical industry, agriculture and households and to elaborate new environmental legislation / guidelines / regulations.

Concerning the studied ecosystems, the most papers were published for freshwater toxicity, followed by marine and terrestrial studies. The most used biological systems were crustaceans and fish followed by insects, mollusks, algae, bacteria and plants. The mono-species tests were the most used in research studies during 2010 2016 followed by multispecies test and twospecies test and in finally community-cosm [1]. This was happening because single species tests were in the routine of laboratories, easy to be reproduced and more economic.

The use of bio-indicators / biomarkers in ecotoxicology is a top subject in fundamental researches in order to prevent, control and solve different environmental pollution issues. A search of the topic "environmental biomarkers" or "environmental bio-indicators" on Wiley Online Platform reveled more than 45000 published documents in the last 10 years, their number maintaining constant for each year, that suggest a great interest for this subject.

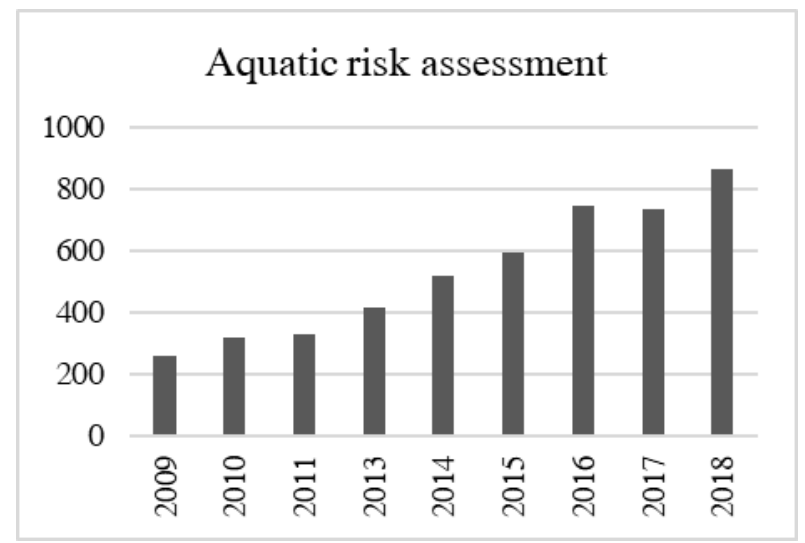

Fig. 1. Trend of ecotoxicological studies published Fig. 2. Trend of aquatic risk assessment studies on Web of Science Platform published on Web of Science Platform 


\section{Legal support of ecotoxicity research in Romania}

The ecotoxicology research represents an important tool of environmental risk assessment studies, hazard characterization of new chemicals or the highlighting of some defense / action mechanisms. Most of these studies have been carried out in a few universities from Romania and national research institutes such as National Research and Development Institute for Industrial Ecology -ECOIND Bucharest (http://www.incdecoind.ro).

The Biotests and Biological Analysis Laboratory of ECOIND Bucharest is the only accredited laboratory from Romania for ecotoxicity testing (aquatic toxicity and biodegradation) for chemical substances / preparations (including commercial detergents), wastewater, surface water, groundwater and leachates. The laboratory has a modern infrastructure with specific equipment's for acclimatization and testing with living organisms obtained following several successive stages of modernization in accordance with the scientific progress.

Modern ecotoxicological methodologies were developed and they are presently in use for the aquatic risk evaluation of different classes ofanthropogenic chemical compounds / industrial chemical preparations / dangerous chemicals and contaminated environmental samples.

\section{Legislative framework}

Most of the studies were based on industry research considering the international norms / guidelines and the requirements for the integration of Romania into the European Union. Below are presented some legal norms that assure the control of chemicals market and prevent the harmful of environment and humans. The REACH legislation (Registration, Evaluation, and Authorization of Chemicals) and their amendments is in force in Romania until June 2008. During 2009 - 2018 great efforts were made to implement and comply the requirements of this program, by chemicals producers and also by ecotoxicology assessment laboratories.

Like other countries, Romania tried to assure a high level of human health and environment protection, as well as the free circulation of the qualitative and environment friendly chemicals on the national and international market and the increase of innovation and competitively, as priorities of environmental and social politics (https://osha.europa.eu/ro).

Regulation (EC) no 1272/2008 on Classification, Labelling and Packaging (CLP) of substances and mixtures is based on the United Nations' Globally Harmonized System (GHS) and its purpose is to ensure a high level of protection of health and the environment, as well as the free movement of substances, mixtures and articles. It requires manufacturers, importers or downstream users of substances or mixtures to classify, label and package their hazardous chemicals appropriately before placing them on the market. The hazard classes in CLP cover physical, health, environmental and additional hazards (https://echa.europa.eu/ro).

Special norms are established for detergents, biocides or pharmaceutical compounds, as well as for the risk assessment.

Detergents Regulation (EC) No 648/2004 establishes common rules to enable detergents and surfactants to be sold and used across the EU, while providing a high degree of protection to the environment and human health. It stipulates that surfactants used in detergents must be fully biodegradable. In addition, it regulates how products should be labelled with ingredient and dosage information in order to protect human health (e.g. skin allergies) and avoid overuse of detergents. This Regulation was updated by Regulation (EU) No 259/2012 which imposes a ban on inorganic phosphates in domestic laundry and dishwasher detergents. Also, the Regulation (EC) no. 66/2010 for EU Ecolabel establish the ecolabel criteria for the product with a reduced environmental impact during their life cycle based on relevant scientific information (especialy biodegrdability and toxicity) - https://eur-lex.europa.eu [2,3].

The Biocide Regulation 528/2012 covers the authorization process and placing of biocide products on market, the exact amount of biocide production. According to guidance the biocides risk assessment needs to be evaluated compartments and in multispecies experimental settings.

Part of chemical mixtures enriches the aquatic environment as anthropogenic pollutants, all marketed chemicals must have a toxicological profile for both humans and animals. For 
ecotoxicological assessment and aquatic risk assessment, laboratory tests on fish, aquatic invertebrates (Daphnia magna), green algae / aquatic plants are mostly recommended; in addition, studies of bio-concentration and behavior in the aquatic environment (water and sediment) - degradation, biodegradation, absorption, etc. are required.

Today, Romania should respond to all European reglementation concerning the chemicals testing according with the OECD Guidelines. The OECD methods on chemical testing summing up more than 150 standards periodically upgraded according to scientific progress, used by authorities, industry or testing laboratories for chemicals ecotoxicological assessment. Moreover, our interest section "Effects on Biotic Systems" include more than 40 biotests with different species (http://www.oecd.org).

The European chemicals safety guidelines promote the reduction of animal (especially vertebrate) testing by introducing the mandatory data sharing requirement and by encouraging the use of alternative testing methods [4]. Microbiotests resulted based on OECD test or ISO / EPA standards as alternative tests more easy to use, economic and reproducible, ready to use for establish the harmful effects of chemicals/contaminated environmental samples on small organisms (invertebrates, algae, ciliates, rotifers, plants and bacteria) $[5,6,7]$.

The aquatic risk assessment is in force since 2003 based on "Technical Guidance Document on Risk Assessment: Commission Directive 93/67/EEC on Risk Assessment for New Notified Substances" publication.

Furthermore, the European Medicines Evaluation Agency (EMEA) and the US Food and Drug Administration (FDA), developed and implemented various environmental risk assessment guidelines for the ecosystems safety $[8,9,10]$. The documents establish the steps for hazard characterization through estimation of PEC (Predicted Environmental Concentration) and PNEC (Predicted Non-Effect Concentration on living organisms) values. The value of PEC/ PNEC ratio is widely accepted as endpoint in aquatic risk assessment model taking into account the unfavorable scenarios [11]. Supplementary, the EU Water Framework Directive 2000/60/EC (WFD), suggests that the hazardous chemicals need to be monitored in
European continental waters in order to protect the water resources quality. The scientific community as well as the EU composed a list of priority substances including harmful chemicals such as: pesticides, metals, volatile organic compound, dioxins, polychlorinated biphenyl compound and recently pharmaceuticals substances, which is regularly upgraded under Water Framework Directive (WFD 2000/60/EC). The Water Directive promote an integrate approach concerning the evaluation of natural receptors through collection and correlation of interdisciplinary data (physical and chemical parameters, as well as biological, ecological, hydro-geomorphological and socioeconomic data).

\section{Methodologies and testing strategies}

Romania developed national programs to ensure the research infrastructure for implementation and development of new testing methodologies to generate new experimental data transferable to governmental authorities, economic agents and academia.

In the field of ecotoxicology were developed adequate procedures in order to evaluate and control the effect of anthropogenic contaminants, more rapid, sensitive and ecofriendly bioassays as well as risk assessments studies [11, 12]. For the ecotoxicity bioassay were needed different species easy to be acclimatized in laboratory conditions, low-cost, sensitive to the toxicants, internationally recognition, representative for the exposed biological system, indigenous species and related to possible changes in the affected ecosystems. Given this, our experimental studies were conducted on various species to cover the entire food chain (table 1). Two species of freshwater fish with economic interest for Romania (Cyprinus carpio and Carassius auratus gibelio), two species of crustaceans (planktonic Daphnia magna and benthic Heterocypris incongruens), one species of green algae (Selenastrum capricornutum renamed Pseudokirchneriella subcapita), one rotifer (Brachiounus calyciflorus), one protozoan (Tetrahymena thermophile), a variety of bacteria species, an aquatic plants (Spirodela polyrhiza) and three terrestrial plants (Lepidium sativum, Sinapis alba, Sorghum saccharatum) were selected to be used in ecotoxicity tests. The mortality / immobilization, growth inhibitions or 
biochemical changes (gene expression) were the most used effect endpoints in the laboratory bioassays. The acute tests $(15 \mathrm{~min}$ to $96 \mathrm{~h}$ period of test) were frequently used to obtain a rapid dose - response $(\mathrm{L}(\mathrm{E}) \mathrm{C} 50)$. The long term effects were underlined through chronic fish test (30-90 days) or ciliates tests $(24 \mathrm{~h})$. The acute effects are the most reproducible and can be calculated with high reliability. Static or semistatic systems were performed for the acute exposure of testing organisms to the contaminants. The bioaccumulation tests were also used for quantified the metal accumulation (bio concentration / bioaccumulation factor (BCF) factors) in the fish or plants tissues in controlled laboratory conditions or directly in surface water / sediment.

In addition, the enzymatic activities and /or histology modifications were assessed to evaluate the effects of toxicants on fish.

Table 1. Biological tests used in INCD ECOIND, Bioassay-Biological Analysis Laboratory

\begin{tabular}{|c|c|c|c|c|c|}
\hline Species & Test & Matrices & $\begin{array}{c}\text { Type of } \\
\text { test }\end{array}$ & Endpoint effect & $\begin{array}{c}\text { Test period } / \\
\text { incubation }\end{array}$ \\
\hline \multicolumn{6}{|l|}{ Freshwater fish } \\
\hline \multirow{4}{*}{$\begin{array}{l}\text { Cyprinus carpio / } \\
\text { Carassius auratus gibelio }\end{array}$} & $\begin{array}{l}\text { OECD } 203 \\
\text { SR EN ISO 7346-1 }\end{array}$ & $\begin{array}{l}\text { Chemical / } \\
\text { water samples }\end{array}$ & acute & $\begin{array}{l}\text { Mortality, LC50 } \\
\text { Clinical signs }\end{array}$ & $96 \mathrm{~h}, 21-22^{\circ} \mathrm{C}$ \\
\hline & In house procedure & $\begin{array}{l}\text { Chemical / } \\
\text { water samples }\end{array}$ & chronic & $\begin{array}{l}\text { Growth instant rate, Mortality rate, } \\
\text { Biomass mean, Production, used } \\
\text { food rate and biochemical indicators } \\
\text { - hepatic enzymes activity, MATC }\end{array}$ & $\begin{array}{l}30-90 \text { days, } \\
21-22^{\circ} \mathrm{C}\end{array}$ \\
\hline & In house procedure & $\begin{array}{l}\text { Chemical / } \\
\text { water samples }\end{array}$ & $\begin{array}{l}\text { acute or } \\
\text { chronic }\end{array}$ & $\begin{array}{l}\text { Enzymatic activity of antioxidant } \\
\text { enzyme } \\
\text { Histopatological modification }\end{array}$ & $\begin{array}{l}>96 \mathrm{~h}, 21- \\
22^{\circ} \mathrm{C}\end{array}$ \\
\hline & $\begin{array}{l}\text { OECD } 305 \\
\text { (Laboratory tests) }\end{array}$ & Metals & $\begin{array}{l}\text { acute or } \\
\text { chronic }\end{array}$ & Bioconcentration factor (BCF) & $\begin{array}{l}>96 \mathrm{~h}, 21- \\
22^{\circ} \mathrm{C}\end{array}$ \\
\hline \multicolumn{6}{|l|}{ Aquatic plants } \\
\hline Spirodela polyrhiza & $\begin{array}{l}\text { ISO 20227, Spirodela } \\
\text { Duckweed Toxkit }\end{array}$ & $\begin{array}{l}\text { Chemical / } \\
\text { water samples }\end{array}$ & acute & Growth inhibition, EC50 & $72 \mathrm{~h}, 25^{\circ} \mathrm{C}$ \\
\hline \multicolumn{6}{|l|}{ Planktonic Crustacean } \\
\hline Daphnia magna & $\begin{array}{l}\text { OECD 202, } \\
\text { Daphtoxkit F }\end{array}$ & $\begin{array}{l}\text { Chemical / } \\
\text { water samples }\end{array}$ & acute & Mortality / immobilization LC50 & $24-48 \mathrm{~h}, 20^{\circ} \mathrm{C}$ \\
\hline \multicolumn{6}{|l|}{ Benthic Crustacean } \\
\hline Heterocypris incongruens & $\begin{array}{l}\text { ISO } 14370 \text {, } \\
\text { Ostracodtoxkit F }\end{array}$ & $\begin{array}{l}\text { Chemical / } \\
\text { water samples / } \\
\text { sediments }\end{array}$ & chronic & Mortality / Growth inhibition, LC50 & 6 days, $25^{\circ} \mathrm{C}$ \\
\hline \multicolumn{6}{|l|}{ Green Algae } \\
\hline $\begin{array}{l}\text { Selenastrum capricornutum / } \\
\text { Pseudokirchneriella subcapita }\end{array}$ & $\begin{array}{l}\text { OECD 201, } \\
\text { Algaltoxkit } \mathrm{F}\end{array}$ & $\begin{array}{l}\text { Chemical / } \\
\text { water samples }\end{array}$ & $\begin{array}{l}\text { acute / } \\
\text { chronic }\end{array}$ & $\begin{array}{l}\text { Growth rate inhibition / biomass } \\
\text { inhibition, EC50 }\end{array}$ & $\begin{array}{c}72 \mathrm{~h}, \\
21-25^{\circ} \mathrm{C} \\
\end{array}$ \\
\hline \multicolumn{6}{|l|}{ Rotifers } \\
\hline Brachiounus calyciflorus & $\begin{array}{l}\text { ASTM Standard Guide } \\
\text { E1440-9, Rotoxk1t F }\end{array}$ & $\begin{array}{l}\text { Chemical / } \\
\text { water samples }\end{array}$ & acute & Mortality, EC50 & $24 \mathrm{~h}, 25^{\circ} \mathrm{C}$ \\
\hline \multicolumn{6}{|l|}{ Protozoan } \\
\hline Tetrahymena thermophila & $\underline{\text { Protoxkit F }}$ & $\begin{array}{l}\text { Chemical / } \\
\text { water samples }\end{array}$ & chronic & Reproduction inhibition, EC50 & $24 \mathrm{~h}, 30^{\circ} \mathrm{C}$ \\
\hline \multicolumn{6}{|l|}{ Bacteria } \\
\hline $\begin{array}{l}\text { Marine luminescent bacteria - } \\
\text { Aliivibrio fischeri }\end{array}$ & $\begin{array}{l}\text { DIN EN ISO 11348-3 } \\
\text { BioFix Lumi }\end{array}$ & $\begin{array}{l}\text { Chemical / } \\
\text { water samples }\end{array}$ & acute & Luminescence inhibition, IC50 & \begin{tabular}{|c|}
$15 / 30 \mathrm{~min}$ \\
$20^{\circ} \mathrm{C}$ \\
\end{tabular} \\
\hline $\begin{array}{l}\text { Microbacterium } \\
\text { sp.,Brevundimonas diminuta, } \\
\text { Citrobacter freundii, } \\
\text { Comamonas testosterroni, } \\
\text { Enterococcus casseliflavus, } \\
\text { Delftia acidovorans, Kurthia } \\
\text { gibsonii, Sthaphilococcus } \\
\text { warnerii, Pseudomonas } \\
\text { aurantiaca, } \\
\text { Serratia rubidae, Pichia } \\
\text { anomalia }\end{array}$ & $\begin{array}{l}\text { MARA test (Microbial } \\
\text { Array for toxicity Risk } \\
\text { Assessment) }\end{array}$ & $\begin{array}{l}\text { Chemical / } \\
\text { water samples }\end{array}$ & acute & Microbial growth inhibition, MTC & $18 \mathrm{~h}, 30^{\circ} \mathrm{C}$ \\
\hline Escherichia coli & $\begin{array}{l}\text { Geno toxicity test } \\
\text { SOS Chromotest }\end{array}$ & $\begin{array}{l}\text { Chemical / } \\
\text { water samples }\end{array}$ & acute & $\begin{array}{l}\text { Effects on genes expression } \\
\text { ( } \beta \text {-galactosidase) }\end{array}$ & $18 \mathrm{~h}, 37^{\circ} \mathrm{C}$ \\
\hline \multicolumn{6}{|l|}{ Terrestrial plants } \\
\hline $\begin{array}{l}\text { Lepidium sativum, } \\
\text { Sinapis alba, Sorghum } \\
\text { saccharatum }\end{array}$ & $\begin{array}{l}\text { SR EN ISO } 11269, \\
\text { Phytotoxkit }\end{array}$ & $\begin{array}{l}\text { Chemical, soil, } \\
\text { sludge, waste, } \\
\text { sediment, water }\end{array}$ & acute & $\begin{array}{l}\text { Germination and root growth } \\
\text { inhibition, EC50 }\end{array}$ & $72 \mathrm{~h}, 25^{\circ} \mathrm{C}$ \\
\hline
\end{tabular}

Note: LC50 / EC50 / IC50 - median lethal / effect / inhibitory concentration; MATC - Maximum Acceptable Toxicant Concentration in aquatic systems, MTC - microbial toxic concentration 
Table 2 Analytical methods for environmental pollutants detection

\begin{tabular}{|c|c|c|}
\hline Environmental pollutants & Analytical methods & Matrices \\
\hline Pesticides & $\begin{array}{l}\text { High-performance liquid chromatography with diode array detection } \\
\text { (HPLC-DAD) / Agilent } 1200 \text { (Agilent Technologies, Germany); } \\
\text { High performance liquid chromatography (HPLC) with multi-waved } \\
\text { detection (MWD) } 1100 \text { (Agilent Technologies, USA); } \\
\text { Liquid chromatographic tandem mass spectrometry method (LC-MS/MS) } \\
1260 \text { / 6410 Agilent (triple quadrupole MS equipped with an electrospray } \\
\text { ionization /ESI source); }\end{array}$ & $\begin{array}{c}\text { Water } \\
\frac{[17,18,19,}{\underline{20]}}\end{array}$ \\
\hline Pharmaceuticals & $\begin{array}{l}\text { High performance liquid chromatography (HPLC) with multiwaved } \\
\text { detector (MWD) } 1100 \text { (Agilent Technologies, USA) } \\
\text { Liquid chromatographic tandem mass spectrometry method (LC-MS/MS) } \\
1260 \text { / } 6410 \text { Agilent (triple quadrupole MS equipped with an electrospray } \\
\text { ionization /ESI source) }\end{array}$ & $\begin{array}{c}\text { Water } \\
{[21,22]}\end{array}$ \\
\hline Metals & $\begin{array}{l}\text { Inductively coupled plasma atomic emission spectrometry (ICP-EOS) } \\
\text { technique, Optima } 5300 \text { DV Perkin Elmer } \\
\text { High performance microwave digestion system, Milestone Ethos } \\
\text { Atomic absorption spectrometry (AAS) with and without enrichment } \\
\text { Could-vapor atomic absorption spectrometry (CV-AAS) }\end{array}$ & $\begin{array}{l}\text { Water / soil / } \\
\text { biota / fish } \\
\text { organs } \\
{[23,24,25]}\end{array}$ \\
\hline Surfactants & $\begin{array}{l}\text { Disulfide blue method } \\
\text { Orange II method }\end{array}$ & $\begin{array}{c}\text { Water } \\
{[26]}\end{array}$ \\
\hline
\end{tabular}

Our data accumulated over the time, allowed us to conclude that the use of microbiotests (with algae, crustacean and bacteria) have had a good reproducibility, relevant and specific results. Otherwise, because the vertebrate represents the final target of aquatic pollution, the toxicity tests with fish have an important role in risk assessment, therefore this can be used in combination with microbiotests.

The multi - species tests can offer relevant data concerning the chemicals risk that may lead to an economical and efficient assessment of acute and chronic toxicity $[13,16]$. In the Fig. 3 the acute testing plan of chemicals under REACH Regulation applied in the ecotoxicity studies was presented.

Firstly, the data about the chemical / chemical product/ environment sample were collected to have a predicted vision about their toxicity in water. Considering the Klimisch score to evaluate the quality of experimental data [27] the need for future information and what test should be performed were established. If the data are not sufficient for risk assessment, new tests are needed.

Secondly, tests using algae, Daphnia and bacteria were performed to obtain de lowest EC50 (effective concentration with inhibition / mortality/ immobilization effect for $50 \%$ of tested organisms set as upper threshold The results led to predict the maximum allowable surface water concentrations, predicted non effect concentrations and also to estimate the concentration - UTC) [28]. The smallest EC50 between algae and crustacean will be used for acute LC50 biotests with fish.

If no mortality was observed, the test was stopped and LC50 greater than (>) the UTC value was reported. If the mortality was observed the test continue at low concentrations using a dilution factor until no mortality was observed.

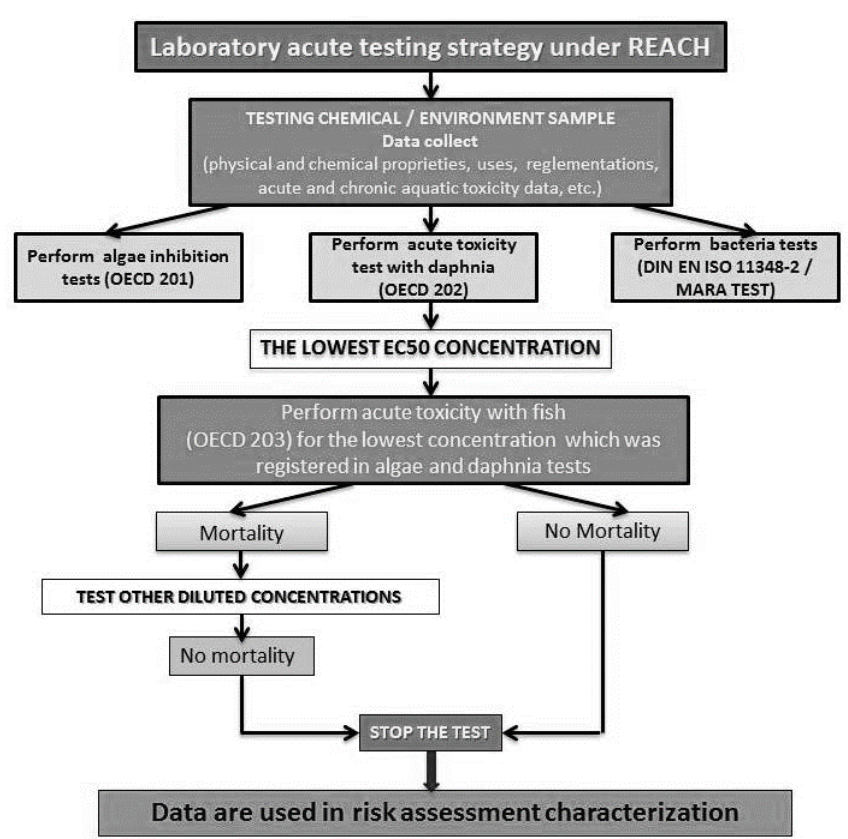

Fig. 3. Acute toxicity laboratory testing plan under REACH [13]

environmental risk coefficients $[10,11]$.

By regularly consulting of the stage of knowledge's in the research field, our 
ecotoxicity topics are fitted in the international development requirements. A statistical analysis of the frequency uses of fish in toxicity tests during the last 10 years revealed a $60 \%$ decrease in 2018 compared to 2009 due to the implementation of new testing strategies and the use of invertebrates in the first stage of toxicity assessment (Figure 4). Because the fish, daphnia

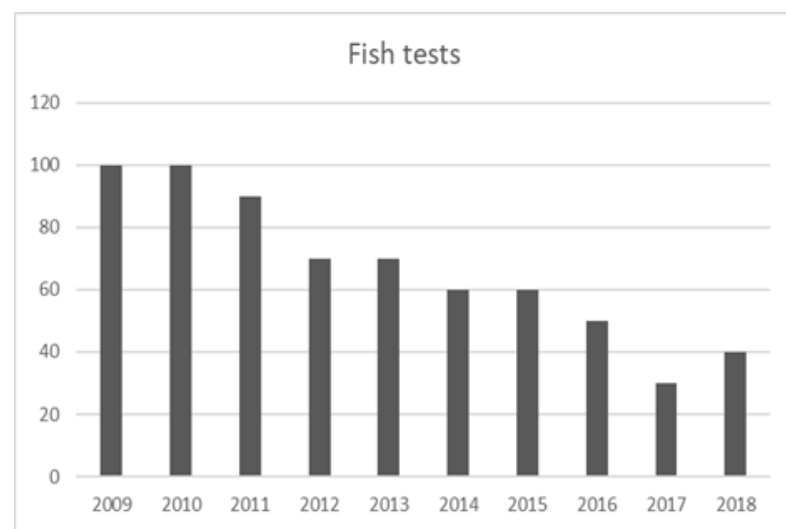

Fig. 4. The fish toxicity test trend in the period 2009-2018

In this context the next paper sections will present the most important results obtained in the least 10 years of ecotoxicological research. The studies were focused on ecotoxicological characterization of chemicals or environmental samples using bio-indicators or biomarkers. Generally, the aquatic risk assessment representing de the end point of ecotoxicological studies.

\section{RESULTS AND DISCUSSIONS \\ Aquatic toxicity - Mono-species experiments}

The single species toxicity tests were appropriate for analyzing toxicological effects on individual characteristics of species such as mortality or growth, but with limited significance for the consequences on the natural ecosystem.

Before 2008, our laboratory performed LC50 individual species tests using fresh water bio indicators such as Cyprinus carpio and Daphnia magna to evaluate the acute or chronic toxicities of various chemicals (pesticides, metals or other inorganic or organic compounds) [11, 29]. Currently, this tests are frequently request by producers or control authorities for chemical products authorization (such as biocide, industrial products or industrial wastes) or environmental samples toxicity control. and algae methods are accredited and required by the economic media, their frequency in the last period was higher compared to the other species (such as bacteria and other small organisms) (Figure 5). Also, ecotoxicity and risk assessment studies have included test batteries that specifically targeted these three species, their use being internationally regulated.

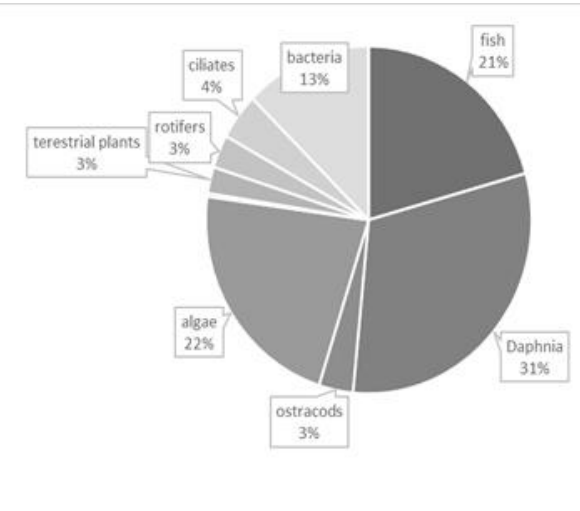

Fig. 5. Frequency of biotests use in period 20092018

The ecotoxicity studies with single species tests were performed in case of: i) chronic tests with fish (Cyprinus carpio) to highlight the chemical bioconcentration or sublethal effects using enzymatic activity or protein expression; ii) efficiency tests with algae (Selenastrum capricornutum / Pseudokirchneriella subcapita) developed for the algaecide efficiency test; ii) or in research studies when the species are selected to be bio-indicator of natural ecosystem.

To assess the toxic hazard of contaminated sediment samples, meiobenthic ostracods Heterocypris incongruens were used as bioindicator for a six days' chronic test.

The percentage of organism's growth-inhibition was assessed. The research study involved the spatial and temporal monitoring of some physical, chemical and biological indicators both from water and sediment and subsequently a correlation with the laboratory ostracods toxicity test was made. The toxicity tests presented a realistic view of field effects. The effects on benthic organisms were directly influenced by a mixed content of contaminants from sediment, especially in those Danube areas where the anthropogenic activities were more intense (Ivancea and Murighiol). This fact was correlated with the benthic diversity from this area [6]. Others specific studies were performed 
to evaluate the subacute effects of chemicals using the biomarkers expressed in living organism such as: antioxidant defense enzymes, hepatic enzymes or protein expression. Chemicals such as: benzenthonium chloride (quaternary ammonium compound - cationic surfactant), cocamidopropyl betaine (zwitterionic compound amphoteric), atrazine and mevinphos (organophosphorus pesticides), trichlorfon and monolinurone (organochlorine pesticides) were tested. The level of oxidative stress biomarkers (superoxide dismutase - SOD, catalase - CAT, glutathione peroxidase - GPx, glutathione reductase - GR, glutathione S transferase - GST, glucose -6- phosphate dehidrogenase - G6PDH) and of lipid peroxidation - LPO were evaluated. After 96h of exposure, the toxicity of surfactants $(1 \mathrm{mg} / \mathrm{l})$ is selective at organs levels. The liver and gills were the most affected by toxic action. The enzymatic biomarkers assessment highlighted deficit in reactive oxygen species balance followed by oxidative stress in fish organs [30, 31]. Also, it was proved that acute intoxication of fish with atrazine $(10 \mathrm{mg} / \mathrm{l})$ and mevinphos $(0.1 \mathrm{mg} / \mathrm{l})$ inhibit the enzymatic activity of MnSOD and CuZnSOD, the detoxifying function of SOD enzyme being discredited, resulting in high death rate during the test [32]. Also, trichlorphon $(1 \mathrm{mg} / \mathrm{l})$ and monolinuron $(1.5 \mathrm{mg} / \mathrm{l})$ could induce an easy change in antioxidant enzymatic activity in fish liver [33].

The hepatic enzymes activity of glutamic oxaloacetic transaminase (GOT) and glutamic pyruvic transaminase (GPT) were used as biomarkers of acute toxicity of some industrial products (fluids used in metalic processing). The tests suggested that the products do not have significant effect on detoxification system and the mixtures could be considerate ecological products [34].

The protein expression in algae extracts were used to evaluate the toxicity of two pesticides (bentazon and 4-chloraniline).

After seven days of test, a differentiated expression of cellular protein was showed according to chemical structure of contaminant, concentration and exposure time. New adaptation or defense proteins were identified in the protein profile comparative with the control. The results are in the publication process.

Aquatic toxicity - Two-species experiments
In the context of new interest of the European Commission concerning the improvement of the environmental performance of products and the increase the demand for more sustainable goods and production technologies by 2030, our laboratory developed ecotoxicity test suitable for each class of chemicals including the biocide.

The use of two species from the same trophic level test is exceptionally applied to showed the sensibility difference. A study of biocides lethal and sub lethal effects was performed using two representative crustacean Daphnia magna (pelagic system) and Heterocypris incongruens (benthic system). The tests showed a significant difference of sensitivity between species. The biocides induced a very toxic or toxic effect on Daphnia magna. On the contrary, the observed ostracods lethal effects were less than 50\% mortality and no significant growth inhibitions were observed [35].

\section{Aquatic toxicity - Three-species experiments}

The phytotoxic effects of some contaminated environmental matrices such as metal / petroleum products polluted soil or sewage sludge were test for three days in the same condition using three higher plants Sorghum saccharatum, Lepidium sativum and Sinapis alba. The inhibition of germination and roots growth inhibition were monitored. The anthropogenic pollutants from the contaminated samples determined different sensitivity responses. The tests could be use as routine toxicity screening tests to provide rapid informations for soil contamination [36], waste water or sludge reuse [37, 38], bioremediation and environmental risk assessment.

\section{Aquatic toxicity - Multi-species experiments}

The biotests battery is based on acute sensitivity responses of a various representative species of trophic chain in order to predict the natural system behavior to the chemical contamination distress. The multi-species tests include species of algae, crustacean, fish, and also rotifers, plants or bacteria. Thereby, a series of specific laboratory studies were performed to assess the toxicological effects of cationic and amphoteric surfactants [39], pharmaceutical compounds (analgesics, antibiotics, nervous stimulators) [16], pesticides [11] and other organic compounds complexed with metals [40]. The final results allowed us: i) to reveled a differentiated response for each trophic chain 
level; ii) to establish a specific effect concentration (LC50/ EC50/ IC50/NOEC); iii) to classified the toxicity hazard according to international norms for chemical classification; iv) to select the unfavorable case (the most sensitive organism); v) to evaluate the PNEC values taking in consideration de environmental dilution factors; vi) to calculate the risk coefficients considering the real contamination of natural water.

The organism's sensitivity depended on chemical class, exposure time or tested concentration.

Generally, the chemicals designed for a specific target organism (such as antibiotics / biocide / some surfactants with biocide action for bacteria or pesticide for plant photosynthesis inhibition) generated toxicity on this species or related to them. A statistical analysis of acute toxicity results obtained in period of 2008 - 2011 revealed that $60 \%$ of results showed that Daphnia magna is the most sensitive to chemical exposure (respectively pesticides, anilines, nitroderivates, metals and surfactants and other dangerous organic compounds) [11]. Fish and bacteria were affected in $15 \%$ from tests. Algae responded only in case of some cationic surfactants or biocide with algaecide action.

The biotests battery was also applied to evaluate the complementary toxicity generated by surfactant biodegradation in laboratory condition. Using a classification system of effluent toxicity [36] based on acute toxicity data of at least three different aquatic species (fish, algae and daphnia), was concluded that some cationic surfactant (such as benzenthonium chloride) persists in the biodegradation effluents, being classified as toxic acute for aquatic system especially for bacteria and algae [26, 39].

The performance of some waste water or drinking water treatment technologies for the natural or anthropogenic pollutants removal, were evaluated through the effluents toxicity testing. For example, flotation processes that use caffeic acid complexed with $\mathrm{Cr}$ (III) and $\mathrm{Pb}$ (II) were monitored for effluents toxicity using a multi species battery. The experiment showed that pelagic crustacean and luminescent bacteria were the most sensitive. On the fish, algae and gram positive and negative bacteria no toxic effects were observed [40].

Danube River and Danube Delta water and sediment were tested and diagnosed for their toxicity using a battery tests with producers (algae - Selenastrum capricornutum, plants Sorghum saccharatum, Lepidium sativum, Sinapis alba) and consumers (rotifers Brachionus calyciflorus, crustaceeans Daphnia magna, Heterocypris incongruens). The water toxicity was classified according to the hazard classification system for natural water. The effect percentages (EP) or $\mathrm{LC} / \mathrm{EC} 50 \%$ of each type of organisms is transformed in toxicity units (TU) using formula: $\mathrm{TU}=100 / \mathrm{EP}$ (LC/EC50\%.) The current classification system is based on acute toxic / hazard being divided in five hazard classes [41]. The largest number of water toxic responses was observed in case of algae, followed by crustaceans and rotifers. In case of sediment, the order was ostracods followed by plants [15].

\section{Aquatic toxicity - Bioconcentration /} bioacumulation

Bioconcentration studies represented a novelty for our laboratory due to the test complexity and also because of analytical challenges. Some nonclinical studies, similar with the pollution of some rivers (Danube River or Olt River), were performed for bioconcentration capacity of heavy metals $(\mathrm{Cu}, \mathrm{Zn}, \mathrm{Ni}, \mathrm{Mn}$ or $\mathrm{Hg})$ in common carp (Cyprinus carpio). It was found that the metals are bioacumulated in organs and tissues as followed: liver > kidneys > gills> gonads > red muscles > white muscles $>$ skin $>$ brain $=$ heart $>$ intestines. Differences in metal concentration between individuals or between receptor organ (e.g. liver versus kidneys or gills) were highlighted, suggesting the specificity in metals metabolism [23, 42]. Interesting results were obtained using field samples (organs of Cyprinus carpio and Carrasius gibelio) as well bivalves (Dreissena sp. and Anodonta sp.) collected from Olt River. The total $\mathrm{Hg}$ content was above the limit allowed by the World Health Organization $(0.5 \mathrm{mg} / \mathrm{kg})$ in muscle and spleen samples harvested from carp specimens. In benthic invertebrate specimens, the $\mathrm{Hg}$ content ranged from 0.19 to $0.52 \mathrm{mg} / \mathrm{kg}$ dry matter in internal organs, while $\mathrm{Hg}$ value in shells was below the method quantification limit [23]. 
More results and final conclusion of metals bioconcentration studies are in publication process. Other studies used lichens Parrmelia spp. as biosensors in the monitoring of environmental pollution with heavy metals $(\mathrm{Cd}$, $\mathrm{Zn}, \mathrm{Pb})$. The lichens have classified the polluted sites by the characteristics of bioaccumulation of metals in lichens. Based on the corticols lichens specificity a correlation index of air quality in the interest geographical areas was calculated. Also, the capacity to accumulate metal in the lichen communities has been used to identify the level of air pollution due road traffic. Based on the degree of heavy metal accumulation such as $\mathrm{Cd}, \mathrm{Cr}, \mathrm{Cu}, \mathrm{Fe}, \mathrm{Mn}, \mathrm{Pb}, \mathrm{Ni}$ and $\mathrm{Zn}$ in the Parmelia spp. lichens, a correlation has been made, with the road traffic. According to the metal bioaccumulation degree in lichens tissue, it has been established that the sources such as traffic from the outskirts of cities, from the perimeter of gas stations and of county roads continuously spread products which contain these elements, into the atmosphere [43].

The aquatic plants such as Lemna minor L. has been reported to accumulate toxic metals and is therefore used as an experimental model to investigate the accumulation of heavy metals. The study shows that the Lemna minor L., accumulates considerable amounts of $\mathrm{Zn}, \mathrm{Cu}$ and $\mathrm{Ni}$ without any symptoms of toxicity [44].

\section{Risk assessment studies}

The ecosystem health is usually based on risk assessment considering the chemical concentration in the environment (PEC) and the impact on organisms (PNEC). A ratio of PEC/PNEC $<1$ indicated no aquatic risk and no future assessments is deemed necessary.

Our studies on chemical risk assessment applied the international methodology adjusted to our laboratory conditions and indigenous organisms. After 2009, the final results of our research studies was to obtain an risk study. The integrated chemicals risk studies involved data of chemical detection in laboratory and field condition, toxicity experimental data of chemical on living organisms, biodegradability, environmental contaminated samples collection (toxicity testing and chemical detection), sub lethal effects evaluation, selection of the most sensitive organisms and risk level establishment (Fig. 6).

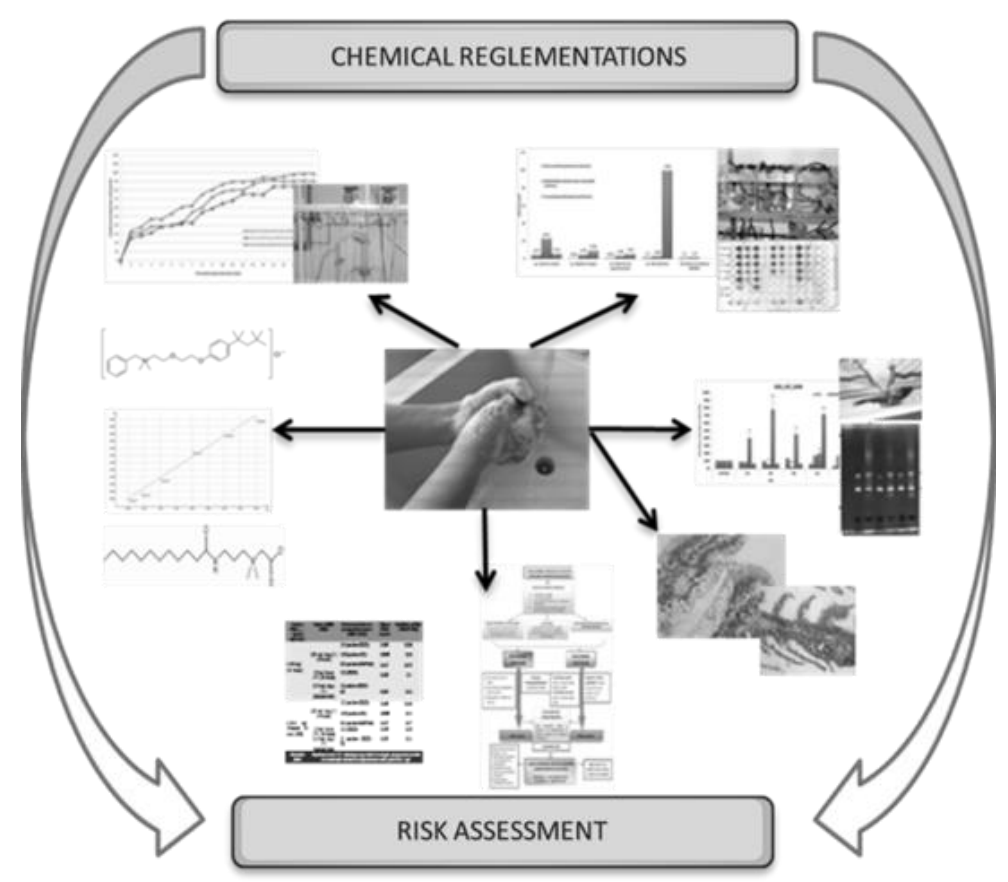

Fig. 6. Chemical aquatic risk assessment

Thereby, risk characterization researches were initiated for some hazardous chemicals (4chloroaniline, 1-chloro-4-nitrobenzene and 4chloro-2-nitrotoluene), pesticides (azinphos- methyl and bentazone), pharmaceuticals (diclophenac, acetaminophen, ketoprophen, indomethacin, naproxen, ibuprophen, carbamazepine, caffeine, ciprofloxacine and 
trimethoprim), surfactants (benzenthonium chloride and cocamidopropyl betaine) and heavy metals. The studies showed the risk level of each chemical compound base on field data concentration respectively Romanian surface waters (Danube River, Danube Delta, Arges River, Mures River, Ciorogarla River and Ghimbasel stream) comparatively with other international rivers $[11,16,29]$. The results showed different levels of risk in accordance to detected environmental concentration, to acute and chronic toxicities and the environmental compartment (water or sediment). High level of risk for water compartment for ciprofloxacin, benzenthonium-chloride, azinphos methyl and arsenic were showed [16, 29]. Moderate risk for diclofenac and ibuprofen was estimated [16].

\section{CONCLUSIONS}

The research national program of Romanian Research and Innovation Ministry supported in the last 10 years' various studies on the toxic effects and aquatic risk generated by the anthropogenic chemicals. The Biotests Biological Analyses Laboratory of National Research and Development Institute for Industrial Ecology ECOIND Bucharest developed and implemented ecotoxicological methodologies for different classes of chemical compounds / industrial chemical mixtures / dangerous chemicals and contaminated environmental samples and characterization of aquatic risk.

The results were used at socio-economic level (creation of new services, partnerships / collaborations with SMEs / universities, development personal training, external visibility) and in environmental protection (providing useful information to manufacturers / importers and control authorities) or for in the establishment of new research partnerships.
The research studies results were quantified as follows: seven experimental studies and methodology for toxic effect evaluation on aquatic organisms for different classes of chemicals and aquatic risk assessment; two experimental studies for characterization and hazard classification of contaminated environmental samples; seven toxicity tests that could be offered as services; eight new detection methods; three $\mathrm{PhD}$ thesis; more than 30 ISI published papers; more than 150 citations; three chapters book; more than 30 conferences / symposiums participation; about new 100 customers. Also, beside of the NUCLEU projects (2009-2018), other seven national research project and a European cooperation in science and technology - COST action was developed. After 10 years of experience the most demanding issues in ecotoxicology studies were: 1) the identification of relevant and reproducible data sources and 2) the access to authority's databases such as consumptions and discharges of pollutant type. In addition, there are still gaps in understanding of regulations and in communication between environmental authority's, testing laboratory, producer / importer and not least the consumer. Given that, great efforts are being made to collect and sort information on testing / interpreting and reporting results so that the final result correspond to the ultimate standards.

Our future interests are to expand the research at molecular level in order to understand the pathways involved in acute and chronic toxicity and predict the mortality, to implement new OECD tests (such as early stage assay) and to use alternative tests (chemical exposure of fish cell line and bioaccumulation). We intend to develop biomarkers to assess the toxicity effect of a large range of pollutants on various biological models.

ACKNOWLEDGEMENTS. These researches were performed by National Research and Development Institute for Industrial Ecology Bucharest with the financial support of the Romanian Research and Innovation Ministry in the period of 2009 - 2018 (NUCLEU Program, CEEX Program, Inovation Program, POS CCE Program, POC Program). 


\section{REFERENCES}

1. LYUBENOVA, M., BOTEVA, S., Biotests in Ecotoxicology: Current Practice and Problems, chapter 7 in „Toxicology - New Aspects to This Scientific Conundrum” edited by Marcelo Larramendy and Sonia Soloneski, ISBN: 978-953-51-2717-8, IntechOpen, 2016, p.147.

2. GHEORGHE, S., LUCACIU, I., PASCU, L., J. Environ. Prot. Ecol., 13, no.1, 2012, p. 155.

3. GHEORGHE, S., LUCACIU, I., GRUMAZ, R., J. Environ. Prot. Ecol., 12, no. 3A, 2011, p. 1525.

4. LILliCRAP, A., BELANGER, S., BURDEN, N., DAVID, D.P., EMBRY, M.R., et al., Environ. Toxicol. Chem., 35, 2016, p. 2637.

5. SZKLAREK, S, STOLARSKA, M., WAGNER, I., MANKIEWICZ-BOCZEK, J., Environ. Monit. Assess., 187, no. 16, 2015, p. 15.

6. STOICA, C., GHEORGHE, S., LUCACIU, E.I., STANESCU, E., PAUN, C.I., NICULESCU, L.D., Soil Sediment Contam. , 23, no.7, 2014, p. 763.

7. PERSOONE, G., WADHIA, K., Comparison Between Toxkit Microbiotests and Standard Tests, DOI: 10.1007/978-0-387-88959-7_23, In book: Ecotoxicological Characterization of Waste, 2009.

8. FENT, K., WESTON, A.A., CAMINADA, D., Aquatic Toxicology, 76, 2006, p. 122.

9. STRAUB, J. O., Toxicology Letter, 131, 2001, p. 137.

10. EMEA, Guideline on the environmental risk assessment of medicinal products for human use; The European Agency for the Evaluation of Medicinal Products, London, England, EMEA/CHMP/SWP/4447/00, http://www.emea.eu.int/pdfs/human/swp/444700en.pdf.

11. GHEORGHE, S., LUCACIU, I., PAUN, I., STOICA, C., STANESCU, E., J. Environ. Prot. Ecol., 15, no. 3, 2014, p. 878.

12. GHEORGHE S., LUCACIU, I., GRUMAZ, R., SGEM 2010, 21-26.06.2010, Albena, Bulgaria., p. 669.

13. GHEORGHE, S., LUCACIU, I., STANESCU, E., STOICA, C., J. Environ. Prot. Ecol., 14, no.2, 2013, p. 601.

14. LUCACIU, I., LUCA, M., ORBAN, T., GHEORGHE, S., GRUMAZ, R., Interntional Symposium - The Environment and Industry, Bucharest, SIMI 28-30.09.2009, p. 214.

15. GHEORGHE, S., STOICA, C., PAUN, I., LUCACIU, I., NITA-LAZAR, M., CRISTOFOR, S., J. Environ. Prot. Ecol., 17, no.1, 2016, p. 171.

16. GHEORGHE, S., PETRE, J., LUCACIU, I., STOICA, C., NITA-LAZAR, M., Environ. Monit. Assess., 188, no. 6, 2016, p. 379.

17. VOSNIAKOS, F., PETRE, J., PASCU, L., VASILE, G., IANCU, V., STANILOAE, D. NICOLAU, M., CRUCERU, L., GOLUMBEANU, M., Fresenius Environmental Bulletin, 19, no. 1, 2010, p. 21.

18. IANCU, V.I., GALAON, T., PETRE, J., CRUCERU, L., PASCU, L., $15^{\text {th }}$ International Multidisciplinary Scientific GeoConference SGEM 2015.

19. IANCU, V.I., PETRE, J., CRUCERU, L., Environ. Prot. Ecol., 12, no. 3, 2011, p. 833.

20. IANCU, V.I., GALAON, T., PETRE, J., CRUCERU, L., PASCU, L. FLORENTINA, L., CAROL B., Rev. Chim. (Bucharest), 67, no. 8, 2014, p. 1484.

21. GALAON, T., PETRE, J., IANCU, V.I., CRUCERU, L., VASIlE, G., PASCU, L.F., BLAZIU L.C., Rev. Chim. (Bucharest), 67, no.8, 2016, p.1474.

22. PETRE, J., IANCU, V., VASIlE, G., AlBU, F., NICULESCU, M., NICUlAE, A. CRUCERU, L., NICOLAU, M., The GeoConference on Ecology, Economics, Education and Legislation, vol. 1, 2013, p. 71.

23. VASILE, GG., GHEORGHE, S., ENE, C., SERBAN, EA., STOICA, C., Rev. Chim. (Bucharest), 70, no.1, 2019, p. 263.

24. VASILE, G., TANASE, IG., Rev. Roum. Chim., 53, no. 11, 2008, p.1041.

25. DINU, C., VASILE, G.,CRUCERU, L., J. Environ. Prot. Ecol., 14, no. 4, 2013, p. 1515. 
26. GHEORGHE, S., LUCACIU, I., PAUN, I., STOICA, C., STANESCU, E., book chapter 4, Biodegradation - Life Science, edited by Dr. Rolando Chamy and Francisca Rosenkranz, ISBN 978-953-51-1154-2, Editor InTech DTP, 2013, p. 83.

27. KLIMISCH, H.J., ANDREAE, M., TILLMANN, U., Regulatory Toxicology and Pharmacology, 25, 1997, p.1.

28. ESAC, (2005). Peer Review of European Commission, Proposal for a new testing strategy (Step-down approach) to reduce the use of fish in acute aquatic toxicity testing, Joint Research Centre.

29. GHEORGHE, S., STOICA, C., NITA-LAZAR, M., GEANINA, VASILE, G., LUCACIU, I., Metals toxic effects in aquatic ecosystems: modulators of water quality, in Water Quality, Book Chapter 4, In: Water Quality, InTech, Hlanganani Tutu(Ed.), DOI: 10.5772/65744, 2017, p. 59.

30. GHEORGHE, S., LUCACIU, I., DINISCHIOTU, A., CATALINA, S., IULIANA, P., Interntional Symposium, The Environment and Industry, Bucharest, SIMI 16-18.10.2011, vol. 2, p. 232.

31. IVAN (GHEORGHE), S., STAN, M., DAMACHE, G., STOICA, C., STANESCU, E., IRINA, L., DINISCHIOTU, A., Effects of Cocamidopropyl betaine on Oxidative stress biomarkers of the Cyprinus carpio sp., $3^{\text {rd }}$ SETAC CEE Annual Meeting, 17-19 September 2012, Cracovia, Polonia, "Ecotoxicology revisited", p. 33.

32. IVAN, S., LUCACIU, I., RUSU, G., VASILE, I., J. Environ. Prot. Ecol., 11, no. 1, 2010, p. 247.

33. GHEORGHE, S., RUSU, G., LUCACIU, I., IANCU, V., J. Environ. Prot. Ecol., 12, no. 3A, 2011, p. 1301.

34. LUCACIU, I., GHEORGHE, S., PETRE, J., GRUMAZ, R., Interntional Symposium - The Environment and Industry, Bucharest, SIMI 28-30.09. 2009, p. 321.

35. GHEORGHE, S., STOICA, C., LUCACIU, I., BANCIU, A., NITA-LAZAR, M., Rev. Chim. (Bucharest), 70, no.1, 2019, p. 307.

36. GHEORGHE, S., VASILE, G., IANCU, V., LUCACIU, I. Romanian Journal of Plant Protection, 4, 2013, p. 43.

37. GHEORGHE, S., PAUN, I., BANCIU, A., VASILE, G., IANCU, V. I., NITA-LAZAR, M., Interntional Symposium - The Environment and Industry, Bucharest, SIMI 29-30.10.2015.

38. GHEORGHE， S., VASILE， GG., STOICA， C., NITA-LAZAR， M., LUCACIU， I., BANCIU, A., Rev. Chim. (Bucharest), 67, no. 8, 2016, p. 1469.

39. GHEORGHE, S., LUCACIU, I., GRUMAZ, R., STOICA, C., J. Environ. Prot. Ecol., 13, no. 2, 2012, p. 541.

40. CRAIOVEANU, MG., GHEORGHE, S., LUCACIU, I., STOICA, L., CONSTANTIN, C., Rev. Chim. (Bucharest), 65, no.3, 2014, p. 339.

41. PERSOONE, G., et al., Environ. Toxicol., 18, no. 6, 2003, p. 395.

42. GHEORGHE, S., VASILE, GG., GLIGOR, C., LUCACIU, IE., NITA-LAZAR, M., Rev. Chim. (Bucharest), 68, no. 8, 2017, p. 1711.

43. MASU, S., Animal Sci and Biotechn, 50, no.1, 2017.

44. NEIDONI, D.-G., NICORESCU, V., ANDRES, L., IHOS, M., LEHR, C.B., Accumulation of toxic metals in aquatic plants, DOI: http://doi.org/10.21698/simi.2018.ab30. 